Mastering

\title{
British Politics
}




\section{Macmillan Master Series}

\begin{tabular}{ll} 
Accounting & Intranets \\
Advanced English Language & Italian \\
Advanced Pure Mathematics & Italian 2 \\
Arabic & Java \\
Banking & Manufacturing \\
Basic Management & Marketing \\
Biology & Mathematics \\
British Politics & Mathematics for Electrical and \\
Business Administration & Electronic Engineering \\
Business Cornmunication & Microsoft Office \\
Business Law & Modern British History \\
C Programming & Modern European History \\
C++ Programming & Modern World History \\
Chemistry & Network Operating Systems \\
COBOL Programming & Pascal and Delphi Programming \\
Communication & Philosophy \\
Database Design & Photography \\
Economic and Social History & Physics \\
Economics & Psychology \\
Electrical Engineering & Science \\
Electronic and Electrical Calculations & Shakespeare \\
Electronics & Social Welfare \\
English Grammar & Sociology \\
English Language & Spanish \\
English Literature & Spanish 2 \\
French & Statistics \\
French 2 & Study Skills \\
German & Systems Analysis and Design \\
Global Information Systems & Visual Basic \\
Internet & World Religions \\
\hline
\end{tabular}

Macmillan Master Series

Series Standing Order ISBN 978-0-333-69343-8

(outside North America only)

You can receive future titles in this series as they are published by placing a standing order. Please contact your bookseller or, in case of difficulty, write to us at the address below with your name and address, the title of the series and the ISBN quoted above.

Customer Services Department, Macmillan Distribution Ltd Houndmills, Basingstoke, Hampshire RG21 6XS, England 


\section{Mastering}

\section{British Politics}

Fourth edition

F.N. Forman

and

N.D.J. Baldwin

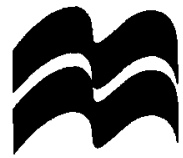


(C) F.N. Forman 1985, 1991

(C) F.N. Forman and N.D.J. Baldwin 1996, 1999

All rights reserved. No reproduction, copy or transmission of this publication may be made without written permission.

No paragraph of this publication may be reproduced, copied or transmitted save with written permission or in accordance with the provisions of the Copyright, Designs and Patents Act 1988, or under the terms of any licence permitting limited copying issued by the Copyright Licensing Agency, 90 Tottenham Court Road, London W1P 9HE.

Any person who does any unauthorised act in relation to this publication may be liable to criminal prosecution and civil claims for damage.

First edition 1985 reprinted four times

Second edition 1991 reprinted four times

Third edition 1996

Fourth edition 1999

Published by

MACMILLAN PRESS LTD

Houndmills, Basingstoke, Hampshire RG21 6XS

and London

Companies and representatives

throughout the world

ISBN 978-0-333-76548-7 ISBN 978-1-349-15045-8 (eBook)

DOI 10.1007/978-1-349-15045-8

A catalogue record for this book is available

from the British Library.

$\begin{array}{llllllllll}10 & 9 & 8 & 7 & 6 & 5 & 4 & 3 & 2 & 1\end{array}$

$\begin{array}{llllllllll}08 & 07 & 06 & 05 & 04 & 03 & 02 & 01 & 00 & 99\end{array}$ 
To the memory of

J.F.R.F. and D.A.M.B. 
List of figures

\section{Part 1 The Political and Electoral Context 1}

1 British political culture $\quad 3$

1.1 Key characteristics 3

1.2 Other significant features $\quad 13$

$\begin{array}{ll}1.3 \text { The European context } & 15\end{array}$

$\begin{array}{ll}1.4 \text { Conclusion } & 17\end{array}$

2 The evolving constitution $\quad 20$

2.1 Key characteristics 20

2.2 Views of the constitution 23

2.3 Pressures for change 27

2.4 Conclusion 32

3 The electoral system $\quad 35$

3.1 The system today $\quad 39$

3.2 Criteria of assessment 48

3.3 The debate 53

3.4 Conclusion 55

4 Voting behaviour $\quad 59$

4.1 Groups in the electorate 61

4.2 Main influences on voting 69

$\begin{array}{ll}4.3 \text { Conventional wisdom } & 78\end{array}$

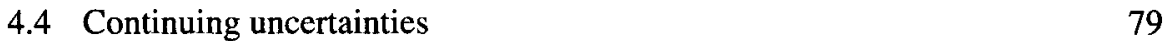

4.5 Conclusion $\quad 85$ 
5 The political parties

5.1 Origins and historical development 91

$\begin{array}{lr}5.2 & \text { Ideological principles } \\ 5.32\end{array}$

$\begin{array}{lr}5.3 \text { Political functions } & 105\end{array}$

$\begin{array}{ll}5.4 \text { National organisation } & 108\end{array}$

$\begin{array}{ll}5.5 \text { Constituency activities } & 118\end{array}$

$\begin{array}{ll}5.6 \text { Conclusion } & 123\end{array}$

6 Pressure groups 128

6.1 Classification of groups 129

6.2 Main functions 131

6.3 Channels of influence 133

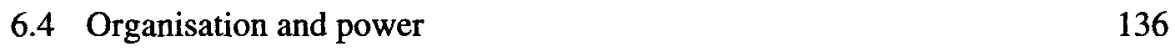

6.5 Involvement in politics 142

$\begin{array}{ll}6.6 \text { Conclusion } & 147\end{array}$

7 The media $\quad 151$

$\begin{array}{lll}7.1 & \text { The current situation } & 151\end{array}$

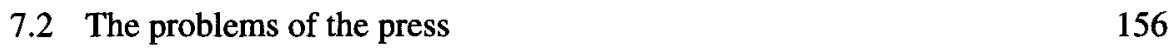

$\begin{array}{ll}7.3 \text { The problems of the electronic media } & 166\end{array}$

$\begin{array}{ll}7.4 & \text { The media and politics } \\ 7.5 & 173\end{array}$

$\begin{array}{ll}7.5 \text { Conclusion } & 177\end{array}$

8 Public opinion $\quad 182$

8.1 The formation of opinion 183

8.2 The sources of opinion $\quad 186$

8.3 The effects of opinion 195

$\begin{array}{ll}\text { 8.4 Public opinion in context } & 199\end{array}$

8.5 Conclusion 204

$\begin{array}{ll}\text { Part } 3 \text { Parliament } & 209\end{array}$

9 The Monarchy 211

9.1 Origins and historical development 212

$\begin{array}{ll}9.2 \text { Powers and functions } & 215\end{array}$

$\begin{array}{ll}9.3 \text { Financing the Monarchy } & 225\end{array}$

9.4 The Monarchy, the media and the public 228

9.5 Conclusion 232

10 The House of Lords 235

10.1 Origins and historical development 235

10.2 Composition 239

10.3 Powers and functions $\quad 242$

10.4 The work and impact of the Lords 248

10.5 Proposals for change $\quad 251$

10.6 Conclusion 256 
$\begin{array}{lr}11.1 \text { Composition } & 259\end{array}$

11.2 The power of the Commons 265

$\begin{array}{ll}11.3 \text { Main functions } & 274\end{array}$

11.4 The progress of reform $\quad 281$

$\begin{array}{ll}11.5 \text { Conclusion } & 285\end{array}$

\section{Part 4 Central Government $\quad 289$}

12 Prime Minister and Cabinet 291

12.1 Historical development 291

12.2 The Cabinet and its support $\quad 292$

$\begin{array}{ll}12.3 \text { Prime Ministerial power } & 300\end{array}$

$\begin{array}{ll}12.4 \text { Cabinet Government } & 309\end{array}$

12.5 Conclusion $\quad 315$

13 Ministers and Departments 319

13.1 The structure and work of Departments 320

$\begin{array}{ll}\text { 13.2 The role of Ministers } & 327\end{array}$

13.3 The problems of Government 333

$\begin{array}{ll}13.4 \text { Conclusion } & 335\end{array}$

14 The Civil Service $\quad 339$

14.1 Composition and functions $\quad 339$

14.2 Key issues $\quad 344$

14.3 Methods of control $\quad 354$

14.4 Executive Agencies and other developments $\quad 364$

$\begin{array}{ll}14.5 \text { Conclusion } & 369\end{array}$

\section{Part 5 The Wider Public Sector $\mathbf{3 7 3}$}

15 The changing role of the state 375

15.1 The orbit of Central Government $\quad 375$

$\begin{array}{ll}15.2 \text { Public corporations } & 383\end{array}$

$\begin{array}{ll}15.3 \text { Privatisation } & 386\end{array}$

15.4 Regulation and control $\quad 390$

15.5 Prospects for the public sector $\quad 394$

$\begin{array}{ll}15.6 \text { Conclusion } & 396\end{array}$

16 Devolved and local government 398

$\begin{array}{ll}\text { 16.1 Devolved government } & 398\end{array}$

16.2 Local government - structure and personnel 404

16.3 Local government - powers and functions 415

16.4 Local government - financial arrangements 418

$\begin{array}{ll}16.5 \text { Central-local relations } & 421\end{array}$

16.6 Methods of central control $\quad 423$

16.7 Whither local government? $\quad 427$

16.8 Conclusion $\quad 429$ 
17 The legal system $\quad 434$

17.1 Criminal justice $\quad 435$

$\begin{array}{ll}17.2 \text { Civil justice } & 439\end{array}$

17.3 Judicial appeal $\quad 441$

17.4 Citizens and the state $\quad 444$

17.5 The role of the police $\quad 452$

17.6 Administrative law $\quad 455$

17.7 Conclusion $\quad 462$

Part 6 Democracy in Britain 469

18 Britain in Europe $\quad 471$

$\begin{array}{ll}\text { 18.1 Historical background } & 471\end{array}$

18.2 Legal and constitutional implications $\quad 478$

18.3 Political and institutional impact $\quad 484$

18.4 Possible future developments 493

$\begin{array}{ll}18.5 \text { Conclusion } & 498\end{array}$

19 Policy and decision making $\quad 503$

19.1 Stages in the process $\quad 504$

$\begin{array}{ll}19.2 \mathrm{Key} \text { aspects } & 513\end{array}$

$\begin{array}{ll}19.3 \text { Strengths and weaknesses } & 517\end{array}$

19.4 Possible improvements $\quad 519$

19.5 Conclusion $\quad 522$

20 British Parliamentary democracy $\quad 525$

20.1 The conditions of democracy $\quad 525$

20.2 Essential characteristics $\quad 526$

20.3 Other significant features $\quad 530$

20.4 Signposts to the future $\quad 534$

20.5 Conclusion $\quad 536$

Name index $\quad 538$

Subject index $\quad 542$ 
1.1 Map of the British Isles 5

1.2 The British political spectrum 9

2.1 Classic view of the constitution $\quad 24$

2.2 Governmental view of the constitution $\quad 25$

2.3 Empirical view of the constitution 26

3.1 A day in the 1997 General Election campaign: the party leaders 37

3.2 Example of a ballot paper $\quad 42$

3.3 Party election spending $\quad 43$

3.4 Voting by party in $1997 \quad 45$

3.5 The eleven Euro regions in the United Kingdom 49

4.1 Political map of the United Kingdom 1997 General Election $\begin{array}{ll}\text { constituency results } & 60\end{array}$

4.2 How Britain voted in 1997, region by region 67

4.3 Profile of the electorate 1979-1997 70

4.4 Electoral volatility 1992 to $1997 \quad 83$

4.5 Electoral volatility in $1997 \quad 84$

5.1 Party policies at the 1997 General Election 100

5.2 Party consolidated income and expenditure accounts for the year $\begin{array}{ll}\text { ended } 31 \text { December } 1997 & 107\end{array}$

$\begin{array}{ll}\text { 5.3 Labour Party organisation } & 109\end{array}$

5.4 Conservative Party organisation 113

$\begin{array}{ll}\text { 5.5 Liberal Democrat Party organisation } & 117\end{array}$

6.1 Pressure group involvement in politics 143

7.1 Main national newspapers in Britain 153

7.2 The electronic media in Britain: a simplified chronology 155

$\begin{array}{lll}\text { 7.3 Press Code of Practice } & 161\end{array}$

8.1 The flow of public opinion 183

$\begin{array}{ll}\text { 9.1 British Monarchs since the Norman conquest } & 214\end{array}$

$\begin{array}{ll}\text { 9.2 Functions of the Monarchy } & 224\end{array}$

9.3 The Royal Family's working year 226

$\begin{array}{ll}9.4 & \text { Financing the Monarchy } \\ \end{array}$ 
10.1 Composition of the House of Lords: 19 November 1998

10.2 Political affiliation in the House of Lords: 19 November 1998

10.3 Sessioncl statistics, 1950-1951 to 1997-1998 249

10.4 The work of the House of Lords, 1950-1951 to 1997-1998 249

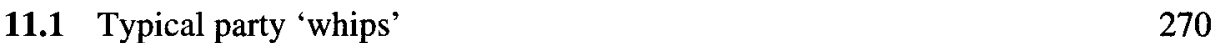

11.2 Functions of the House of Commons 275

12.1 Prime Ministers since Robert Walpole 293

12.2 Ministerial Committees of the Cabinet 296

12.3 The Prime Ministers' Support Structure (1998) 301

12.4 Prime Ministerial powers 303

13.1 The structure of central Government (1998) 321

13.2 Cabinet Office and Office of Public Service organisation chart 322

13.3 Government Department: standard structure 324

14.1 Civil Service staffing levels 341

14.2 The Civil Service - important dates 344

14.3 Civil Service Code, $1996 \quad 351$

14.4 Executive Agencies in $1998 \quad 358$

15.1 The composition of the public sector 376

15.2 The network of Ministerial patronage 377

$\begin{array}{lll}15.3 & \text { Privatisations since } 1979 & 388\end{array}$

15.4 The regulatory framework 393

16.1 English Government Regions 403

16.2 The chronology of change: key dates in English local
government history

16.3 England: Counties and Unitary Authorities, 1 April 1998

16.4 Wales: Unitary Authorities, 1 April $1998 \quad 409$

16.5 Scotland: Council Areas, 1 April $1998 \quad 410$

16.6 Northern Ireland: Districts, 1 April 1998

16.7 The structure of Government in the United Kingdom 412

16.8 Average hours per month Councillors spent on Council duties 414

16.9 Responsibility for some major services in English Local Authorities 417

16.10 Local government expenditure and income 419

17.1 The Court system 436

17.2 Key British defeats before the European Court of Human Rights 446

18.1 The development of European Integration 474

$\begin{array}{ll}\text { 18.2 European integration: a chronology } & 475\end{array}$

18.3 The European Union prospects of enlargement 477

18.4 The European decision-making process 488

18.5 Areas and extent of European involvement and legal competence 492

19.1 The policy and decision-making process 504 
This book is a general introduction to the British system of Government and politics. It is an attempt to convey clear information about every significant aspect of the subject and to facilitate an understanding of the British political system and contemporary British politics.

Since the third edition of this book was published in 1996, a great deal of consequence has happened in British politics. Most noticeably, the Conservative Party finally met its Waterloo and was swept out of office at the 1997 General Election by a bored and contemptuous electorate. It was replaced by a new Labour Government led by Tony Blair with the largest Parliamentary majority ever achieved in the history of the Labour Party. Combined with the psychological effects of the looming millennium, this seems to have had a substantial impact upon the public mood and possibly on British political culture, long considered to be one of the most stable and admirable aspects of British society.

The new public mood appears more than ready to give Tony Blair and his colleagues a considerable amount of latitude within which to take forward their project of 'modernisation' - a long word which can evidently be stretched to encompass everything from turning the Labour Party into a highly professional election winning machine with the minimum of ideological baggage to reforming Britain's age-old Parliamentary institutions and, in due course perhaps, even its electoral system. At the same time the Nationalist parties in Scotland, Wales and Northern Ireland have all benefited from the willingness of 'New Labour' to make some timely and historic concessions to the Nationalist pressures emanating from all parts of the Celtic fringe; and the Liberal Democrats enjoyed New Labour's willingness to explore, albeit rather tentatively, various ways of narrowing the gap between the two parties of the centreLeft in Britain - a gap which became a chasm in the early years of this century when labour gradually replaced the fragmented and increasingly marginalised Liberals as the principal opponent of the Tories.

Another large theme which is evident in British politics at the turn of the century is the accelerating erosion of the nation state and all its works; such that its political institutions are challenged from above and below, its jurisdiction is challenged from within and without, and its traditional competences are challenged by new power centres principally to be found in the global media and financial markets. Both the process of political competition and the substance of political culture are inevitably 
affected by these formidable forces which owe their allegiance to no particular territory, jurisdiction or state. The result is that it is becoming harder to speak of 'British politics' as an authentic and recognisably distinct area of study or social experience; and people living in these islands, as elsewhere, are increasingly seeing themselves as individuals rooted essentially in their immediate localities but identifying also with the wider communities of Europe and the world.

For this edition of the book the practical consequences are that we have felt it necessary to emphasise: the considerable changes in Britain's evolving constitution (Chapter 2); the sea-change in voting behaviour which was reflected in the result of the 1997 General Election (Chapter 4); the transformation of all the institutions of Parliament to a greater or lesser extent (Chapters 9-11); the shrinking role and capacities of the nation state (Chapter 15); the changing structures of sub-national government (Chapter 16); and the softer, fuzzier nature of governance in Blairite Britain. Of course, not everything has changed in a few years. Britain and its political system will be as recognisable to students and practitioners of politics in the early years of the twenty-first century as they are at the tail end of the twentieth century. Nevertheless we hope it will be apparent to those who read this book, whether they are already familiar with the subject or come new to it, that British politics are an endlessly fascinating subject which repays close study by experts and laymen alike.

As in previous editions, many people have helped in the preparation and development of the text. We would particularly like to thank Sheila Tofts and Amanda Mabbitt for their typing skills (and endless patience), Suzannah Tipple and her colleagues at Macmillan for their encouragement and support, and Sally Vince for her editorial assistance. We must record our gratitude to those who have over the years helped with the content through general discussion or through reading and commenting upon various draft chapters: Charles Anson, Mary Baber, Sir Robin Butler, Lord Lawson, Lord Merlyn-Rees, Richard Mottram, Sir Patrick Nairne, Professor Lord Norton of Louth, Chris Pond, Professor Rod Rhodes, Peter Riddell, Michael Welsh and David Willetts. Our thanks are also due to all those individuals - in Government Departments, Agencies, public bodies and other groups - who provided us with information.

Any insights achieved in this edition - and indeed in earlier editions - owe a great deal to these individuals. Any errors of fact or opinion are, of course, entirely our responsibility.

London and Wroxton

F.N. Forman

February 1999

N.D.J. Baldwin 
The authors and publishers wish to thank the following for permission to use copyright material: Philip Allan Publishers Ltd for Fig. 4.1 from article by J. Garland and M. Rowe, Politics Review, 7:1 (September 1997); Tim O'Donovan for data in Fig. 9.1 from his letter to The Times, 2.1.98; Guardian News Service Ltd for data in Fig. 3.2 from The Guardian. 18.11.97 Copyright $\odot$ The Guardian; The Controller of Her Majesty's Stationery Office for crown copyright material in Figs. 5.2, 13.2, 14.1, 14.3, 16.8, 16.9, from the Civil Service Code, CM 4014 1998, CM4057 5th rpt Committee on Standards in Public Life, DETR data, and Civil Service Yearbook; MORI for data in Fig. 4.3; Vacher Dod Publishing Ltd for material in Figs. 12.2, 14.4 from Vacher's Parliamentary Companion, 1998 Newspaper Publishers Association for data in Fig. 7.1.

Every effort has been made to trace the copyright-holders, but if any have been inadvertently overlooked the publishers will be pleased to make the necessary arrangement at the first opportunity. 